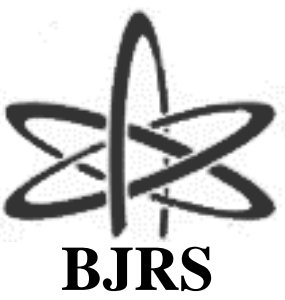

\author{
BRAZILIAN JOURNAL \\ $\mathrm{OF}$ \\ RADIATION SCIENCES \\ 06-02 (2018) 01-11
}

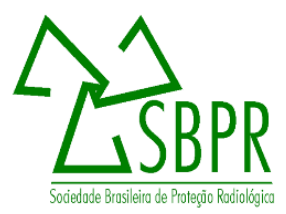

\title{
Operational intervention levels for reactor emergencies: IAEA recommendations
}

\author{
L. A. de Aguiar ${ }^{\mathrm{a}}$; A. A. dos Reis ${ }^{\mathrm{a}} ;$ R. dos $\operatorname{Santos}^{\mathrm{a}}$ \\ ${ }^{a}$ Institute of Radiation Protection and Dosimetry - IRD, Brazilian Nuclear Energy Commission - CNEN \\ Av. Salvador Allende, s/n, 22783-127 Rio de Janeiro, RJ, Brazil \\ laguiar@ird.gov.br; arlene@ird.gov.br; raul@ird.gov.br
}

\begin{abstract}
The IAEA publication EPR-NPP-OILs-2017, OPERATIONAL INTERVENTION LEVELS FOR REACTOR EMERGENCIES AND METHODOLOGY FOR THEIR DERIVATION [1], provides selected default OIL values, describing a methodology for their derivation, as well as practical tools and recommendations for their use. IAEA recommends that tools and default OIL values be directly integrated into national emergency arrangements or reviewed and modified as necessary to meet the specific emergency preparedness and response arrangements. The Institute of Radiation Protection and Dosimetry (IRD) has a Radiological Assessment Team (EAR) as part of its Radiation Emergency Response System. Brazilian regulatory standards address actions for radiation emergencies encompassing necessary measures to assess public exposures, intervention levels to protect the public and recommendations for protective actions as evacuation, relocation, sheltering and food restrictions. The objective of this paper is to present a discussion on the use of these OILs, to compare them to those established by the Brazilian standards and to propose a methodology on how OILs can be used by EAR/IRD in case of an emergency at the Brazilian NPP.
\end{abstract}

Keywords: OIL, Reactor Emergencies, Radiological Assessment. 


\section{INTRODUCTION}

Operational Interventional Levels (OILs) are operational criteria that allow the prompt implementation of protective actions and other response actions on the basis of monitoring results that are readily available during a nuclear or radiological emergency [1]. The use of OILs as part of the protection strategy for nuclear and radiological emergencies is recommended by IAEA Safety Standards Series No. GSR Part 7 [2].

In advance, as part of preparedness process to respond an emergency, OILs should be developed for: isolation of contaminated area or dangerous source; evacuation or substantial shelter; stable iodine prophylaxis; decontamination of people; decontamination or control of vital equipment, vehicles and personal property; immediate medical treatment; long term medical follow-up; countermeasures against excessive doses from ingestion; and control of international trade, goods and products [3].

The IAEA publication EPR-NPP-OILs-2017, OPERATIONAL INTERVENTION LEVELS FOR REACTOR EMERGENCIES AND METHODOLOGY FOR THEIR DERIVATION [1], provides selected default OIL values, together with a detailed description of the methodology for their derivation, as well as practical tools and recommendations for their use. A default OIL value is a specific value of such a measured quantity that indicates the need to implement predetermined response actions (e.g. evacuation, relocation, food restrictions). IAEA recommends that tools and default OIL values provided in such publication be directly integrated into national emergency arrangements or be reviewed and modified as necessary to meet the specific emergency preparedness and response arrangements of the country in which they will be applied.

The Radiological Evaluation Team (EAR) is part of the Radiological and Nuclear Emergency Response System at the Radioprotection and Dosimetry Institute (IRD - Brazil), which acts in accordance with IAEA recommendations and national regulatory system. Members of EAR participated of Pilot Training Course on the Development and Use of Operational Intervention Levels for Severe Emergencies at Light Water Reactor organized by IAEA before the publication of EPRNPP-OILs-2017 providing a detailed explanation on how to use the IAEA's default operational levels (OILs) as well as on the methodology for their derivation and revision. 
Brazilian regulations address measures for radiation emergencies encompassing necessary actions to evaluate public exposures, intervention levels to protect the public, protective actions as evacuation, relocation, sheltering and food restrictions. These standards have been updated according the international recommendations.

The objective of this work is to discuss the OILs methodology presented in the recent IAEA publication EPR-NPP-OILs-2017, to compare them to those presented in Brazilian standards and to present how OILs will be used by EAR/IRD as tool in case a NPP emergency. The response actions implemented based on the default OIL values are intended to minimize radiation induced health effects that would reduce quality of life.

\section{IAEA PUBLICATION}

\subsection{Background}

The effectiveness of the response to radiation emergency is related to a prompt and adequate implementation of protective action to mitigate the hazard. IAEA recommends the use of OILs as tool to allow the decision makers immediately action, so it is required the use of OILs as part of the protection strategy for nuclear and radiological emergencies. IAEA addressed OILs by the following documents: Safety Standards Series No. GSR Part 7 [2], Safety Standards Series No.GS-G-2.1 [3], GSG-2 [4], EPR-NPP Public Protective Actions [5] and TECDOC-955 [6].

The IAEA-TECDOC-955 [6] provides tools, procedures and data needed to evaluate the consequences of a nuclear accident occurring at a nuclear power plant throughout all phases of the emergency, namely, before, during and after the release of radioactive material. The scope of this publication is restricted to the technical assessment of radiological consequences. In its procedure B1 Public Protective Action Assessment presents the nine operational intervention levels (OILs): Two OILs for during a release (based on projections and in plume ambient dose rate measurements) and seven OILs for after a plume passage (three are based on ambient dose rates measurements of deposition, two based on ground deposition levels and two based on the concentration of activity in food, milk and water). The technical guidance for response actions and OILs contained in IAEA- 
TECDOC-955 [6], presented in Table 1, are superseded by other IAEA publications: IAEA-EPRNPP-OILs-2017 [1], IAEA-GS-G-2.1 [3], IAEA-GSG-2 [4] and IAEA-EPR-NPP Public Protective Actions [5].

Table 1: Default OILs from IAEA-TECDOC-955 [6].

\begin{tabular}{|c|c|c|c|}
\hline Basis & OIL No & \multicolumn{2}{|c|}{ Default Criteria } \\
\hline \multirow{2}{*}{ Ambient dose rate in plume } & 1 & \multicolumn{2}{|c|}{$1 \mathrm{mSv} / \mathrm{h}^{\mathrm{a}}$} \\
\hline & 2 & \multicolumn{2}{|c|}{$0.1 \mathrm{mSv} / \mathrm{h}$} \\
\hline \multirow{3}{*}{ Ambient dose rate from deposition } & 3 & \multicolumn{2}{|c|}{$1 \mathrm{mSv} / \mathrm{h}$} \\
\hline & 4 & \multicolumn{2}{|c|}{$0.2 \mathrm{mSv} / \mathrm{h}$} \\
\hline & 5 & \multicolumn{2}{|c|}{$1 \mu \mathrm{Sv} / \mathrm{h}$} \\
\hline Ground deposition levels & & General Food $(\mathrm{F})$ & Milk (M) \\
\hline $\mathrm{I}-131$ & 6 & $10 \mathrm{kBq} / \mathrm{m}^{2}$ & $2 \mathrm{kBq} / \mathrm{m}^{2 \mathrm{~b}}$ \\
\hline Cs-137 & 7 & $2 \mathrm{kBq} / \mathrm{m}^{2}$ & $10 \mathrm{kBq} / \mathrm{m}^{2 \mathrm{~b}}$ \\
\hline Food, milk, water concentrations & & General Food (F) & Milk (M) \\
\hline $\mathrm{I}-131$ & 8 & $1 \mathrm{kBq} / \mathrm{kg}$ & $0.1 \mathrm{kBq} / \mathrm{kg}$ \\
\hline Cs-137 & 9 & $0.2 \mathrm{kBq} / \mathrm{kg}$ & $0.3 \mathrm{kBq} / \mathrm{kg}$ \\
\hline
\end{tabular}

${ }^{\mathrm{a}}$ If there is no indication of core damage, OIL1 $=10 \mathrm{mSv} / \mathrm{h}$

${ }^{\mathrm{b}}$ For goat milk multiply by 0.10

The IAEA Safety Standards Series GSG-2 (Criteria for Use in Preparedness and Response for a Nuclear or Radiological Emergency) [4] presents a coherent set of generic criteria (expressed numerically in terms of radiation dose) that form a basis for developing the operational levels needed for decision making concerning protective actions and other response actions necessary to meet the emergency response objectives. Also it proposes a basis for a plain language explanation of the criteria for the public and for public officials that addresses the risks to human health of radiation exposure and provides a basis for a response that is commensurate with the risks. The Appendix II provides selected examples of six default OILs for deposition, levels of skin contamination, and 
contamination levels for food, milk and water, presented in Table 2, together with a plain language explanation of the OILs.

Table 2: Default OILs from IAEAGSG-2 [4]

\begin{tabular}{|c|c|c|}
\hline Basis & $\begin{array}{l}\text { OIL } \\
\text { No }\end{array}$ & Default Value \\
\hline \multirow{9}{*}{$\begin{array}{l}\text { Environmental } \\
\text { measurements }\end{array}$} & \multirow{3}{*}{1} & Gamma $(\gamma) 1000 \mu \mathrm{Sv} / \mathrm{h}$ at $1 \mathrm{~m}$ from surface or a source \\
\hline & & 2000 counts/s direct beta $(\beta)$ surface contamination measurement \\
\hline & & 50 counts/s direct alpha $(\alpha)$ surface contamination measurement \\
\hline & \multirow{3}{*}{2} & Gamma $(\gamma) 100 \mu \mathrm{Sv} / \mathrm{h}$ at $1 \mathrm{~m}$ from surface or a source \\
\hline & & 200 counts/s direct beta $(\beta)$ surface contamination measurement \\
\hline & & 10 counts/s direct alpha $(\alpha)$ surface contaminationmeasurement \\
\hline & \multirow{3}{*}{3} & Gamma $(\gamma) 1 \mu \mathrm{Sv} / \mathrm{h}$ at $1 \mathrm{~m}$ from surface \\
\hline & & 20 counts/s direct beta $(\beta)$ surface contamination measurement \\
\hline & & 2 counts/s direct alpha $(\alpha)$ surface contamination measurement \\
\hline \multirow{3}{*}{$\begin{array}{l}\text { Skin contami- } \\
\text { nation }\end{array}$} & \multirow{3}{*}{4} & $\operatorname{Gamma}(\gamma) 1 \mu \mathrm{Sv} / \mathrm{h}$ at $10 \mathrm{~cm}$ from the skin \\
\hline & & 1000 counts/s direct beta $(\beta)$ skin contamination measurement \\
\hline & & 50 counts/s direct alpha $(\alpha)$ skin contamination measurement \\
\hline \multirow{3}{*}{$\begin{array}{c}\text { Food, milk } \\
\text { and water } \\
\text { concentrations }\end{array}$} & \multirow{3}{*}{5} & (DEFAULT SCREENING OILs) \\
\hline & & Gross beta $(\beta): 100 \mathrm{~Bq} / \mathrm{kg}$ or \\
\hline & & Gross alpha $(\alpha): 5 \mathrm{~Bq} / \mathrm{kg}$ \\
\hline \multirow{2}{*}{$\begin{array}{l}\text { from laborato- } \\
\text { ry analysis }\end{array}$} & \multirow{2}{*}{6} & (DEFAULT RADIONUCLIDE SPECIFIC OILs) \\
\hline & & Specifics values for each radionuclide in $\mathrm{Bq} / \mathrm{kg}$ \\
\hline
\end{tabular}

From the document IAEA GSG-2 [4], OILs for rates or air concentrations in a plume resulting from an ongoing release are not provided, because they are not practical to be use in an emergency situation due to the following reasons: (a) in many cases the significant release will be over by the time results of environmental measurements are available; (b) it is difficult to take and analyses air concentrations in a sample in a timely manner; (c) there is a great variation in time and location of the plume concentrations at any location during a release; and (d) OILs of these types are highly 
dependent on the nature of the release, which makes it very difficult to develop OILs that apply to the full range of possible releases. It is important to highlight that OILs for air concentrations arising from resuspension are also not provided because doses arising from resuspension have been considered in the deposition OILs [4].

The IAEA Safety Standards GS-G-2.1 (Arrangements for Preparedness for a Nuclear or Radiological Emergency) [3] concerns emergency preparedness for a nuclear or radiological emergency. The range of possible nuclear or radiological emergencies of concern is enormous, extending from a general emergency at a nuclear power plant to emergencies involving lost, stolen or found radioactive material. Therefore, the GS-G-2.1 is intended to be applied to the entire range of emergencies because it addresses the general aspects of emergency preparedness. This publication does not provide any default OILs values, even though they are addressed as fundamental to urgent protective actions.

The EPR-NPP Public Protective Actions 2013 [5] provides an description of the actions necessary to protect the public for those responsible for making and for acting on decisions in the event of an emergency involving actual or projected severe damage to the fuel in the reactor core or spent fuel pool at a light water reactor (LWR) or spent fuel pool. LWRs with power levels greater than $100 \mathrm{MW}$ (th), and spent fuel pools containing reactor fuel that needs to be actively cooled in order to prevent overheating and failure of the fuel. OILs are provided for ground deposition (OIL1, OIL2, OIL3), deposition of radioactive material on the skin (OIL4), dose rate the thyroid from iodine intake (OIL8), as well as food, milk, and water concentrations (OIL7) after a release from a damaged reactor core or spent fuel pool warranting protective and other response actions off the site. The OIL5 and OIL6 are used for other purposes not relevant for a release from a reactor core or spent fuel pool. The Table 3 presents OILs values from EPR-NPP Public Protective Actions 2013 [5].

\subsection{IAEA Publication EPR-NPP-OILs-2017}

The recent IAEA publication EPR-NPP-OILs-2017 [1] provides a detailed description of the methodology for derivation of the default OIL values presented in EPR-NPP Public Protective Actions 2013 [5], as well as practical tools and recommendations for their use. Provides: (a) default OIL values that can be used immediately in the response to an emergency due to severe conditions 
at an LWR or its spent fuel; (b) a detailed explanation of the methodology for deriving the default OIL values; (c) practical tools and recommendations on how to use the OILs; and (d)considerations for revising the default OIL values.

Table 3: Default OILs from IAEA EPR-NPP Public Protective Actions 2013 [5]

\begin{tabular}{|c|c|c|}
\hline Basis & $\begin{array}{l}\text { OIL } \\
\text { No }\end{array}$ & Default Value \\
\hline \multirow{3}{*}{$\begin{array}{l}\text { Ground deposition } \\
\text { dose rates }\end{array}$} & 1 & $\begin{array}{l}\text { Dose rate at } 1 \mathrm{~m} \text { above ground level } \\
\qquad 1000 \mu \mathrm{Sv} / \mathrm{h}\end{array}$ \\
\hline & 2 & $\begin{array}{c}\text { Dose rate at } 1 \mathrm{~m} \text { above ground level } \\
100 \mu \mathrm{Sv} / \mathrm{h}(\leq 10 \text { days after shutdown of the reactor }) \\
25 \mu \mathrm{Sv} / \mathrm{h}(>10 \text { days after shutdown of the reactor })\end{array}$ \\
\hline & 3 & $\begin{array}{l}\text { Dose rate at } 1 \mathrm{~m} \text { above ground level } \\
\qquad 1 \mu \mathrm{Sv} / \mathrm{h}\end{array}$ \\
\hline Skin dose rates & 4 & $\begin{array}{l}\text { Dose rate at } 10 \mathrm{~cm} \text { from skin } \\
\qquad 1 \mu \mathrm{Sv} / \mathrm{h}\end{array}$ \\
\hline $\begin{array}{l}\text { Concentrations of } \\
\text { markers I-131 and } \\
\text { Cs-137 in food, milk } \\
\text { and drinking water }\end{array}$ & 7 & $\begin{array}{l}1000 \mathrm{~Bq} / \mathrm{kg} \text { of I-131 } \\
200 \mathrm{~Bq} / \mathrm{kg} \text { of Cs-137 }\end{array}$ \\
\hline $\begin{array}{l}\text { Dose rate from the } \\
\text { thyroid }\end{array}$ & 8 & $\begin{array}{l}\text { Above background dose rate in contact with the skin in } \\
\text { front of the Thyroid, } 1 \text { to } 6 \text { days after exposure } \\
\qquad \begin{array}{c}0.5 \mu \mathrm{Sv} / \mathrm{h} \text { for Age } \leq 7 \text { years } \\
2 \mu \mathrm{Sv} / \mathrm{h} \text { for Age }>7 \text { years }\end{array}\end{array}$ \\
\hline
\end{tabular}

The default OIL values provided in EPR-NPP-OILs-2017 follows a reasonably conservative approach; they are established below those levels at which radiation induced health effects will be observed, even in a very large exposed group of people composed of the most sensitive members of the public. This publication addresses OILs for a severe release of radioactive material from an 
LWR or its spent fuel, for the following monitoring results: (a) dose rate measurements above the ground; (b) dose rate measurements and beta count rates from the skin; (c) concentrations of marker radionuclides in food, milk and drinking water samples; and (d) dose rate measurements from the thyroid. As can be verified in Table 4, the values are the same as those presented in IAEAEPR-NPP Public Protective Actions 2013 [5].

Table 4: Default OILs from IAEA EPR-NPP-OILs-2017 [1]

\begin{tabular}{|c|c|c|}
\hline Basis & $\begin{array}{l}\text { OIL } \\
\text { No }\end{array}$ & Default Value \\
\hline \multirow{3}{*}{ Ground monitoring } & 1 & $\begin{array}{l}\text { Ambient dose equivalent rate at } 1 \mathrm{~m} \text { above ground level } \\
\text { - } 1000 \mu \mathrm{Sv} / \mathrm{h}\end{array}$ \\
\hline & 2 & $\begin{array}{l}\text { Ambient dose equivalent rate at } 1 \mathrm{~m} \text { above ground level } \\
\text { - } 100 \mu \mathrm{Sv} / \mathrm{h}(\leq 10 \text { days after shutdown of the reactor) } \\
\text { - } 25 \mu \mathrm{Sv} / \mathrm{h} \text { ( }>10 \text { days after shutdown of the reactor) }\end{array}$ \\
\hline & 3 & $\begin{array}{l}\text { Ambient dose equivalent rate at } 1 \mathrm{~m} \text { above ground level } \\
\text { - } 1 \mu \mathrm{Sv} / \mathrm{h}\end{array}$ \\
\hline Skin monitoring ${ }^{a}$ & 4 & $\begin{array}{l}\text { Ambient dose equivalent rate at } 10 \mathrm{~cm} \text { from bare skin of } \\
\text { the hand and face } \\
\text { - } 1 \mu \mathrm{Sv} / \mathrm{h} \\
\text { Beta count rate at } 2 \mathrm{~cm} \text { from the bare skin of the hand } \\
\text { and face } \\
\text { - } 1000 \mathrm{cps}\end{array}$ \\
\hline $\begin{array}{l}\text { Monitoring of food, } \\
\text { milk and drinking } \\
\text { water samples }\end{array}$ & 7 & $\begin{array}{l}\text { Activity concentrations of markers I-131 and Cs-137 } \\
\text { - } 1000 \mathrm{~Bq} / \mathrm{kg} \text { of I-131 } \\
\text { - } 200 \mathrm{~Bq} / \mathrm{kg} \text { of Cs-137 }\end{array}$ \\
\hline Thyroid monitoring & 8 & $\begin{array}{l}\text { Ambient dose equivalent rate in front of the Thyroid in } \\
\text { contact with the skin } \\
\text { - } 0.5 \mu \mathrm{Sv} / \mathrm{h}\end{array}$ \\
\hline
\end{tabular}

${ }^{\mathrm{a}}$ The use of OIL $4 \gamma$ is preferable over OIL $4 \beta$ 
The publication EPR-NPP-OILs-2017 provides stand-alone "OIL charts" (a practical tool for using the default OIL values during the response to an emergency), together with important practical information for using the OILs and making recommendations on warranted response actions. Provides a detailed explanation of the methodology for deriving the default OIL values and a description of the two spreadsheets included on the attached CD, which were used to calculate the default OIL values. Also provides (a) general considerations concerning the revision of the default OIL values to consider different underlying assumptions or another methodological approach and (b) instructions for adapting the default OIL value provided for the beta count rate from activity on the skin to a specific instrument.

The methodology for deriving the default OIL values provided in EPR-NPP-OILs-2017 [1] considers the following elements:

- The OILs are based on the generic criteria given in the IAEA Safety Standards Series No. GSR Part 7. Generic criteria are expressed numerically in terms of radiation doses for which protective actions and other response actions are expected to be undertaken under any circumstances in a nuclear or radiological emergency to avoid or to minimize severe deterministic effects and to reduce the risk of stochastic effects. Radiation induced health effects are not expected to be observed, even in the most sensitive persons as children and pregnant woman.

- The OILs are calculated for all the radionuclide mixes expected to be released from an LWR or its spent fuel during a severe emergency which may be significant contributors to the dose of the public or to the instrument response. In this publication 19 mixes were considered: three of them based in Chernobyl and Fukushima accidents; eleven mixes are based on scenarios of postulated core to containment release; four mixes are based on scenarios of postulated core to atmosphere release; and the last one based on postulated spent fuel release scenario.

- All members of the public have been considered in the calculation of the OILs by taking response actions based on the dose projected or received by the representative person. The representative person is not a specific person with defined characteristics. It is constructed 
depending on exposure scenario that will result in the highest dose to be received by a member of the public including infants up to adults.

- Five exposure scenarios resulting from deposited radioactive material are considered for the OILs provided in this publication. For each exposure scenario, different exposure pathways are considered, which describe the routes by which radiation or radionuclides can reach humans and cause exposure, as described below:

1) Ground scenario - External exposure from radioactive material deposited on the ground, external exposure from resuspended radioactive material, inhalation of resuspended radioactive material and inadvertent ingestion of soil.

2) Food pre-analysis scenario - Ingestion of radioactive material in local produce from the affected area (e.g. garden vegetables or milk) before entrance in the distribution system.

3) Skin scenario - External exposure to the dermis from radioactive material on the skin, inadvertent ingestion of radioactive material on the skin.

4) Food post-analysis scenario - Ingestion of radioactive material in food, milk or drink water from the distribution system.

5) Thyroid scenario - Exposure of the thyroid from radioactive iodine in the thyroid.

- Any behavior of the radionuclides that could have a significant impact on the dose or the OILs is considered: the behavior of the radionuclides (after being released into the environment) and its impact on the dose by deriving a series of factors used in the OIL calculations, e.g. ground weathering, decay, resuspension, transfer from the ground to vegetables and pasture, removal from vegetation by weathering and decay, transfer from cow's feed to cow's milk, reduction in food due to radioactive decay during the period of availability for consumption and removal from the skin by weathering and decay.

- Dose conversion factors relate the activity of a certain radionuclide with the projected dose, which is needed to determine if the generic criteria may be exceeded. The dose conversion factor depends on the radionuclide, the dose quantity, the exposure pathways, the exposure scenario, the exposed individual and other considerations. 
- The instrument response affects the different default OIL values and is considered in the calculations. Some instruments characteristics are required for the OILs applications, e. g. specific quantity, window, distance, etc.

- For each OIL defined a set of time and mix dependent OIL(t, mix) functions is calculated, based on which a default OIL value is chosen. Choosing a default value over a time and/or mix dependent OIL is considered necessary because (a) the mix can vary considerably during an emergency with time and location; and (b) not having a default criterion for the implementation of response actions has led to confusion of decision makers and skepticism among the public in past emergencies, delaying urgently required response actions.

- These response actions were developed by taking into consideration the overall protection strategy outlined in Ref. [2] and the concept of operations outlined in Ref. [5]. The charts provide the default OIL values, together with associated response actions for practical uses.

\section{BRAZILIAN REGULATION}

The Brazilian Nuclear Energy Commission (CNEN) is a federal agency, under the Ministry of Science and Technology, with administrative and financial autonomy, legal personality under public law, which has the following institutional purposes: a) collaborate to the National Nuclear Energy Policy; b) perform actions for research, development, and provision of nuclear technology and its applications for peaceful purposes; and c) regulate, license, authorize, supervise and control such use. The CNEN through the Radioprotection and Nuclear Safety Board (DRS) establishes federal regulation and performs the surveillance and licensing processes in order to enforce the legislation $[7,8]$.

The Brazilian regulation CNEN NN 3.01 [9] establishes the basic requirements for radiation protection of persons related to ionizing radiation exposure. Regard to public exposure, this Brazilian regulation establish (line $\mathrm{d}$, item 5.14.1) that operators must ensure an adequate response to radiological emergency situations that may involve public exposure, including emergency plans or procedures in line with nature and the intensity of the risk involved. Additionally, it is established (item 6.1.3) that in interventions, to protect individuals from the public, the levels of intervention and 
action levels established by CNEN should be observed for the different protective or remediation actions. Furthermore, there are requirements for exposure in an emergency situation (item 6.3). The Regulatory Position 3.01/006:2011 [10] refers to the requirements of the CNEN Standard NN 3.01 expressed in section 6.3, and its application to intervention in emergency situations.

The Regulatory Position 3.01/006:2011 [10] is structured into five main parts: an introduction; early protective actions and generic levels of intervention for urgent protection actions (item 3.2); intervention levels for temporary and definitive relocation (item 3.3); action levels for food control (item 3.4); and default OIL values for pressurized light water reactor (PWR) accidents (item 3.5). Being item 3.5 of Regulatory Position PR 3.01/006:2011 the item of interest for this work. The default OIL values for taking protective actions in Brazilian Regulatory Position 3.01/006:2011 [10] are those published in IAEA-TECDOC-955 [6].

\section{IRD'S RADIOLOGICAL EVALUATION TEAM}

A team of specialists to assess the monitoring results in order to determine, modify or initiate urgent protective actions to protect workers and public using OILs is recommended as arrangements for a response to a nuclear or a radiological emergency [11]. This team also should determine when additional assistance is necessary to dealing with the radiation emergency and how to obtain such assistance.

The IRD Radiological Emergency Plan addresses the Radiological Evaluation Team (EAR) which is formed by environmental analysis specialists, internal and external dosimetry experts and in loco analysis specialists. This team is intended to do the radiological evaluation during an emergency to allow taking protective actions to reduce the exposure of the public and the workers to the radiation.

\section{DISCUSSION}

The IAEA publication EPR-NPP-OILs-2017 provides selected default OIL values for taking protective actions and other response actions to protect the public in an emergency involving a se- 
vere release of radioactive material from a light water reactor or its spent fuel. This publication considers the lessons learned from the accidents at the Chernobyl nuclear power plant and at the Fukushima Daiichi nuclear power plant in Japan. The default OIL values provided follow a reasonably conservative approach; they are established below those levels at which radiation induced health effects will be observed, even in a very large exposed group of people composed of the most sensitive members of the public.

The tools and default OIL values provided in IAEA publication EPR-NPP-OILs-2017 may be directly integrated into national emergency arrangements or reviewed and modified as necessary to meet the specific emergency preparedness and response arrangements of the country in which they will be applied. The methodological approach for default OIL values derivation, as well as practical tools and recommendations for their use are also presented in this publication; therefore the IAEA Member States will meet support to deriving their OILs.

The default OIL values for taking protective actions and other response actions to protect the public in an emergency involving a severe release of radioactive material from reactor in Brazilian Regulatory Position 3.01/006:2011 [10] is based on IAEA-TECDOC-955 [6]. However, as presented before, the OILs contained in IAEA-TECDOC-955 [6] are superseded by IAEA-EPR-NPPOILs-2017 [1], IAEA-GS-G-2.1 [3], IAEA-GSG-2 [4] and IAEA-EPR-NPP Public Protective Actions [5]. Therefore, the Brazilian regulation must be updating to include the news defaults OLIs values for skin and thyroid monitoring, OIL4 and OIL8, respectively. In addition, it is necessary to evaluate whether it is valid to maintain the OILs based on rates or air concentrations in a plume resulting from an ongoing release, which is no longer recommended by the IAEA publications.

The IRD's radiological evaluation team is studying and discussing the principles and methodology presented in the IAEA publication EPR-NPP-OILs-2017 [1] to adapt the default values presented in this publication to the Brazilian reality and, thus, to update the tool used by the Team in emergency situations. 


\section{CONCLUSIONS}

The OILs are a good tool to indicate the need for promptly implementing response actions to protect the public during a nuclear or radiological emergency. The news defaults OLIs values for skin and thyroid monitoring, OIL4 and OIL8, respectively, are very important to identify promptly those for whom skin or thyroid monitoring results exceed OIL4 or OIL8, decontaminate and perform medical screenings. Was an excellent initiative from IAEA had organized a Pilot Training Course on the Development and Use of Operational Intervention Levels for Severe Emergencies at Light Water Reactor organized by IAEA before the publication of EPR-NPP-OILs-2017 and had invited the Member States to provide detailed explanation on how to use the IAEA's default operational levels (OILs) as well as on the methodology for their derivation and revision. The availability of spreadsheets with the equations provides greater agility in the adequacy of default OIL values by the Member States. Keeping the EAR continuously updated not only contributes to the revision of Brazilian standards, but also leaves the team prepared to act promptly in an emergency situation.

\section{ACKNOWLEDGMENT}

The authors are very grateful to IAEA RLA/9076 and Radioprotection and Dosimetry Institute (IRD) of the Brazilian Nuclear Energy Commission (CNEN) for supporting this work.

\section{REFERENCES}

1. INTERNATIONAL ATOMIC ENERGY AGENCY. Operational intervention levels for reactor emergencies and methodology for their derivation. EPR-NPP-OILs (2017). Vienna, March 2017.

2. FOOD AND AGRICULTURE ORGANIZATION OF THE UNITED NATIONS,INTERNATIONAL ATOMIC ENERGY AGENCY, INTERNATIONAL CIVIL AVIATIONORGANIZATION, INTERNATIONAL LABOUR ORGANIZATION, INTERNATIONALMARITIME ORGANIZATION, INTERPOL, OECD NUCLEAR ENERGY AGENCY, PANAMERICAN HEALTH ORGANIZATION, PREPARATORY COMMISSION FOR THECOMPREHENSIVE NUCLEAR-TEST-BAN TREATY ORGANIZATION, UNITEDNATIONS ENVIRONMENT PROGRAMME, UNITED NATIONS OFFICE FOR THECOORDINATION OF HUMANITARIAN AFFAIRS, WORLD HEALTH ORGANIZATION,WORLD METEOROLOGICAL ORGANIZATION, Preparedness and Response for a 
Nuclear or Radiological Emergency, IAEA Safety Standards Series No. GSR Part 7, IAEA, Vienna (2015).

3. FOOD AND AGRICULTURE ORGANIZATION OF THE UNITED NATIONS,INTERNATIONAL ATOMIC ENERGY AGENCY, INTERNATIONAL LABOUROFFICE, PAN AMERICAN HEALTH ORGANIZATION, UNITED NATIONS OFFICEFOR THE COORDINATION OF HUMANITARIAN AFFAIRS, WORLD HEALTHORGANIZATION, Arrangements for Preparedness for a Nuclear or Radiological Emergency, IAEA Safety Standards Series No. GS-G-2.1, IAEA, Vienna (2007).

4. FOOD AND AGRICULTURE ORGANIZATION OF THE UNITED NATIONS,INTERNATIONAL ATOMIC ENERGY AGENCY, INTERNATIONAL LABOUROFFICE, PAN AMERICAN HEALTH ORGANIZATION, WORLD HEALTHORGANIZATION, Criteria for Use in Preparedness and Response for a Nuclear or Radiological Emergency, IAEA Safety Standards Series No. GSG-2, IAEA, Vienna (2011).

5. INTERNATIONAL ATOMIC ENERGY AGENCY, Actions to Protect the Public in an Emergency due to Severe Conditions at a Light Water Reactor, EPR-NPP Public Protective Actions 2013, IAEA, Vienna (2013).

6. INTERNATIONAL ATOMIC ENERGY AGENCY, Generic Assessment Procedures for Determining Protective Actions during a Reactor Accident, IAEA-TECDOC-955, IAEA, Vienna (1997).

7. Brazil. Lei $N^{0} 4,118$. Dispõe sobre a política nacional de energia nuclear, cria a Comissão Nacional de Energia Nuclear, e dá outras providências. 27 de Agosto de 1962.

8. Brazil. Lei No 7,781. Dá nova redação aos artigos $2^{\circ}, 10$ e 19 da Lei no 6.189, de 16 de dezembro de 1974, e dá outras providências. 27 de junho de 1989.

9. Comissão Nacional de Energia Nuclear. CNEN NN 3.01 - Diretrizes básicas de proteção radiológica. Março, 2014.

10. Comissão Nacional de Energia Nuclear. Posição Regulatória 3.01/006:2011 - Medidas de proteção e critérios de intervenção em situações de emergência.

11. INTERNATIONAL ATOMIC ENERGY AGENCY, Method for developing arrangements for response to a nuclear or radiological emergency, EPR-Method 2003, IAEA, Vienna (2003). 